\title{
Investigating Variables and Mechanisms that Influence Protein Integrity in Low Water Content Amorphous Carbohydrate Matrices
}

\author{
Jane F. Povey \\ Protein Science Group, Dept. of Bioscience, University of Kent, Canterbury CT2 7NJ, Kent, U.K. \\ Natalia Perez-Moral, Timothy R. Noel, and Roger Parker \\ Institute of Food Research, Norwich Research Park, Colney, NR4 7UA, Norfolk, U.K.
}

Mark J. Howard and C. Mark Smales

Protein Science Group, Dept. of Bioscience, University of Kent, Canterbury CT2 7NJ, Kent, U.K.

DOI 10.1002/btpr.207

Published online August 18, 2009 in Wiley InterScience (www.interscience.wiley.com).

Biopharmaceutical proteins are often formulated and freeze dried in agents that protect them from deleterious reactions that can compromise activity and authenticity. Although such approaches are widely used, a detailed understanding of the molecular mechanisms of protein stabilization in low water content amorphous glasses is lacking. Further, whilst deterioration chemistries are well described in dilute solution, relatively little is known about the extent and mechanisms by which protein integrity is compromised in the glassy state. Here we have investigated the relationship between protein modification and rate thereof, with variation of $\mathrm{pH}$, carbohydrate excipient, temperature and the glass transition temperature using a model protein, lysozyme. Mass spectrometry analysis and peptide mapping confirm that protein modifications do occur in the glassy state in a time-, temperature-, and carbohydrate excipient-dependent manner. There were clear trends between the buffer $\mathrm{pH}$ and the primary modification detected (glycation). Most importantly, there were differences in the apparent reactivities of the lysine residues in the glass compared with those previously determined in solution, and therefore, the well-characterized solution reactivity of this reaction cannot be used to predict likely sites of modification in the glassy state. These findings have implications for (i) the selection and combinations of formulation components, particularly with regard to glycation in the glassy state, and (ii) the design of procedures and methodologies for the improvement of protein stability in the glassy state. () 2009 American Institute of Chemical Engineers Biotechnol. Prog., 25: 1217-1227, 2009 Keywords: glassy state, formulation, protein stability, freeze drying, glycation

\section{Introduction}

In the in vivo, environment, proteins are sensitive to a number of well-characterized rearrangements, degradations, and chemical reactions that compromise the integrity of these proteins (e.g., the Maillard reaction, deamidation, and oxidation) and lead or contribute toward the progression of various disease states. ${ }^{1}$ Animal species (in addition to others) have, therefore, developed protective mechanisms to either prevent or reverse these damaging reactions, or alternatively to remove and degrade such modified proteins. Such modifications are also observed in proteins in vitro, however, additional degradations and rearrangements are also often observed in solution including hydrolysis (particularly at Asp-Pro motifs), disulphide cross-linking and diketopiperazine formation, ${ }^{2}$ all of which can result in the damaging loss of protein integrity, decreased or abolished bioactivity, and increased immunogenicity.

Correspondence concerning this article should be addressed to C. M. Smales atc.m.smales@kent.ac.uk.
There is, thus, an industrial requirement to prevent such modifications in vitro and preserve the integrity of proteins and peptides in both the food and biopharmaceutical sectors prior to their consumption or use to maintain biological authenticity. With particular regard to the biopharmaceutical industry, this is usually achieved via a range of strategies that involve formulating the protein of interest with protecting agents or excipients that protect the protein from deleterious reactions that might otherwise compromise their activity and authenticity. ${ }^{5,6}$ Often these strategies have been optimized using empirical approaches. ${ }^{7}$

One standard practice/strategy utilized in both the food and biopharmaceutical fields is that of putting the protein/peptide of interest into the glassy state. ${ }^{8,9}$ Practically this involves drying a peptide or protein, often with other glass-forming components, which are typically low molecular weight carbohydrates. ${ }^{10}$ Drying is achieved by processes such as spray drying or freeze-drying. The mechanism by which this strategy prevents modification is thought to be the result of vitrification of the protein-carbohydrate mixture which, during freeze-drying, allows the formation of a readily dried open-pored cake ${ }^{11}$ and 
subsequently, during storage, retards molecular motion and arrests chemical reaction on a practical timescale. A further application of the glassy state is protein stabilization during antiviral dry heat treatments. For example, freeze-dried Factor VIII is routinely treated at $80^{\circ} \mathrm{C}$ for $72 \mathrm{~h}$, conditions that would result in rapid deterioration of the protein in the solution state, however, in the glassy state the protein is protected and virus inactivated. Indeed, we have previously shown that during antiviral dry heat treatment protein modification can occur to protein samples following freeze-drying. ${ }^{12}$

Although proteins dried in the absence of any additives form glasses, ${ }^{13}$ those with added carbohydrate have been shown to have enhanced stability. ${ }^{14}$ It has been proposed that the role of the carbohydrate is that of water replacement. ${ }^{14}$ This is both in a general sense, that is, not only by filling the space which would be occupied by the water in the hydrated system, reducing the extent to which the secondary and tertiary structures of the protein are modified on drying, but also through a more specific interaction of the carbohydrate, particularly the disaccharide trehalose, with the protein which enhances stability.

Although there is a relatively large body of empirical work on how formulation and storage temperature affects the rates at which proteins in the glassy state either aggregate or lose their biological activity, ${ }^{5}$ and there are several studies investigating such changes in the glassy state ${ }^{15,16}$ our understanding of the molecular mechanisms of protein stabilization in glasses in the biotechnological setting is still far from complete. Further, while the deterioration chemistries are well described in dilute solution, relatively little is known about the extent and mechanisms by which protein (and peptide) integrity is maintained, or indeed compromised, by glassy state stabilization technologies. ${ }^{17}$ Particularly at higher temperatures, protein unfolding may facilitate decomposition by new pathways, an area relevant to antiviral dry heat treatments of protein preparations. Although carbohydrate additives have been used to promote thermal stability of proteins, their molecular mechanism remains poorly understood and the potential to control the deterioration chemistry has not been exploited. Furthermore, a better understanding of the relationship between water content, temperature, formulation/carbohydrate excipient, and protein stability will help in the rational development of formulations that prevent or limit such potentially damaging reactions for the improved stability of food and biopharmaceutical products. ${ }^{18,19}$

The aim of this study was to address this gap in our knowledge using the model protein hen egg white lysozyme to investigate the relationship between chemical modification and rate thereof, $\mathrm{pH}$, carbohydrate excipient, temperature, and the glass transition temperature. Mass spectrometry analysis and peptide mapping confirm that protein modifications do occur in the glassy state in a time-, temperature-, carbohydrate-, and $\mathrm{pH}$-dependent manner. These findings have implications for (i) the selection and combinations of formulation components, and (ii) the design of procedures and methodologies for the improvement of protein stability in the glassy state to assure protein product quality.

\section{Materials and Methods}

\section{Materials}

All materials were of analytical reagent grade or better and purchased from Sigma Aldrich unless otherwise stated.
Dextran (molecular weight 40,000) was sourced from Fluka. Commercial hen egg white lysozyme was sourced from Sigma and was of Grade 1 (provided three times recrystallized and lyophilized by the manufacturer).

\section{Preparation of samples and formulations for freeze-drying}

Protein formulations consisting of $5 \mathrm{mg} / \mathrm{mL}$ lysozyme were prepared with industrially relevant $3 \%$ sucrose, trehalose, and dextran excipients at $\mathrm{pH} 6.2,7.2$, or 8.2. To prepare the final solutions ready for freeze-drying, the required amount of excipient was dissolved separately in preprepared $0.1 \mathrm{M}$ sodium phosphate buffer $\mathrm{pH} 6.2,7.2$, or 8.2 containing $5 \mathrm{mg} / \mathrm{mL}$ lysozyme. The resulting protein solutions were then filtered, sterilized, and stored frozen $\left(-20^{\circ} \mathrm{C}\right)$ prior to freeze-drying.

\section{Freeze-drying of samples}

Aliquots $(1 \mathrm{~mL})$ of the appropriate protein formulation (prepared as described above) were pipetted into $2 \mathrm{~mL}$ vials (Adelphi, Haywards Heath, UK) with a predried slotted stopper. The vials were then loaded onto a stainless steel tray and freeze-dried using a Virtis Advantage (EL 2.0) freezedryer (Biopharma Process Systems, Winchester, UK) using the following conditions: freeze the samples until shelf temperature reaches $-45^{\circ} \mathrm{C}$; hold the samples at this temperature for at least $60 \mathrm{~min}$; primary dry at $-35^{\circ} \mathrm{C}$ for $40 \mathrm{~h}$; secondary dry at temperatures rising from -35 to $-10^{\circ} \mathrm{C}$ at 100 mTorr over a period of $66 \mathrm{~h}$ before increasing the temperature to $20^{\circ} \mathrm{C}$ at $70 \mathrm{mT}$ Torr for a further $45 \mathrm{~h}$. This protocol was developed based upon the glass transition behavior of a frozen sucrose-rich system. Often the freeze dryer would be loaded with samples with very different drying characteristics and so a slow drying protocol to accommodate all was used. Vials were then vaccuum dried in a vacuum oven over phosphorus pentoxide for 5 days. Finally, the vials containing the freeze-dried material were closed with a stopper and capped with aluminum caps. The amorphous nature of the samples was confirmed by the absence of crystals when viewed using polarizing light microscopy.

\section{Determination of glass transition temperature and water content in freeze-dried samples}

Glass transition temperatures $\left(T_{\mathrm{g}}\right)$ of freeze-dried samples were determined in triplicate after panning in a glove box under dry nitrogen conditions using a Perkin Elmer DSC 7 differential scanning calorimeter. An initial scan was performed to remove any effects of physical aging of the samples which can affect the apparent glass transition temperatures. $^{20,21} T_{\mathrm{g}}$ 's were determined on a rescan at a scanning rate of $10^{\circ} \mathrm{C} / \mathrm{min}$ as described previously. ${ }^{20,21}$ One exception to the use of this method was the sucrose $\mathrm{pH} 6.2$ samples which were highly susceptible to buffer crystallization and so in this case the $T_{\mathrm{g}}$ was estimated from the first scan. A baseline was subtracted from the scan before analysis. The midpoint transition is quoted as determined by Wunderlich. ${ }^{22}$ The water content of samples was determined in the differential scanning calorimeter (DSC) pans by puncturing the pan with a needle and then drying them to a constant weight (as determined using a Mettler ME30 balance) in a evacuated vacuum oven at $60^{\circ} \mathrm{C}$ over phosphorus pentoxide. After drying samples were cooled in a dessicator to room temperature before measurement. 


\section{Stability studies following freeze-drying of lysozyme in various excipient formulations}

Following freeze-drying, all samples were stored in sealed vials at $-80^{\circ} \mathrm{C}$ until analyzed or used for stability testing. For stability testing and accelerated storage studies the vials containing $1 \mathrm{~mL}$ aliquots of freeze-dried material were stored and incubated at either $-80^{\circ} \mathrm{C}$ (control), ambient temperature $\left(18-20^{\circ} \mathrm{C}\right), 37,55$, or $90^{\circ} \mathrm{C}$ for either $24 \mathrm{~h}, 1$ month, or 16 months, prior to analysis as detailed later. Visual inspection of samples was undertaken immediately after storage and the details recorded. For more detailed molecular analysis, samples were reconstituted in the vial by reconstitution in $1 \mathrm{~mL}$ of $\mathrm{ddH}_{2} \mathrm{O}$.

\section{Measurement of lysozyme activity}

Lysozyme activity was determined by measuring the rate at which a known concentration of enzyme cleared a solution of the bacterial substrate Micrococcus lysodeikticus. Briefly, a $0.5 \mathrm{mg} / \mathrm{mL}$ suspension of Micrococcus lysodeikticus was prepared in PBS ( $\mathrm{pH}$ 6.5) and stored on ice. This suspension was sonicated regularly and frequently to prevent aggregation or clumping of the cells. Reconstituted lysozyme solutions $(20 \mu \mathrm{L})$ were then added to $1 \mathrm{~mL}$ of the substrate solution and the absorbance recorded every $10 \mathrm{~s}$ at $500 \mathrm{~nm}$ until a constant reading was obtained. All samples were analyzed in triplicate and the initial rate of clearance calculated to determine the lytic activity of the lysozyme sample in absorbance units/sec.

\section{Electrospray ionization mass spectrometry analysis of lysozyme following freeze-drying and stability testing}

Mass spectra were recorded in the positive ion mode on a Finnigan MAT LCQ ion trap mass spectrometer and the charge state ion distributions observed in ESI mass spectra deconvoluted as previously described ${ }^{12}$ except that deconvolution was achieved using Excalibur software (version 1.2). Excipients were removed by reverse-phase high-performance liquid chromatography (HPLC) using a $\mathrm{C}_{18}$ reverse-phase column $\left(250 \times 2.0 \mathrm{~mm}^{2}\right.$ i.d., Phenomenex Jupiter, Macclesfield, Cheshire, UK) linked to an Agilent 1100 LC system before the sample was introduced into the mass spectrometer as previously described. ${ }^{12}$

\section{Tryptic peptide mapping}

Reconstituted lysozyme samples were reduced and alkylated with iodoacetic acid essentially as described by Smales et $a{ }^{12}{ }^{12}$ Samples were dialyzed against $8 M$ urea, $0.25 M$ Tris$\mathrm{HCl}$ buffer ( $\mathrm{pH} 8.75$ ) containing $1 \mathrm{mM}$ EDTA and then 2.16 $\mu$ mol dithiothreitol in $100 \mu \mathrm{L}$ of the same buffer was added per $2 \mathrm{mg}$ of lysozyme. The resulting solution was then left to incubate at $37^{\circ} \mathrm{C}$ for $3 \mathrm{~h}$ prior to the addition of iodoacetic acid ( $3 \mu \mathrm{L}$ of a $2 M$ solution per $2 \mathrm{mg}$ of lysozyme). Alkylation was then allowed to proceed in the dark at room temperature for $45 \mathrm{~min}$. $\beta$-mercaptoethanol was finally added $(1 \% \mathrm{v} / \mathrm{v})$ and the alkylated protein dialyzed against $8 M$ urea. After dialysis, the alkylated protein solutions were diluted with $1 \%$ ammonium bicarbonate buffer to give $2 M$ urea solutions. TPCK treated trypsin solution $\left(4 M\right.$ in $\mathrm{H}_{2} \mathrm{O}, 0.05 \%$ TFA) was then added to the digest solution so that an enzyme:substrate ratio of 1.5:100 (w/w) was achieved. The mix- ture was then left to digest for $5.5 \mathrm{~h}$ at $37^{\circ} \mathrm{C}$ before being stored at $-20^{\circ} \mathrm{C}$ until required for further analysis.

Separation of the resulting tryptic fragments was carried out on a $\mathrm{C}_{18}$ reverse-phase column (Phenomenex Jupiter, $250 \times 2.0 \mathrm{~mm}^{2}$ i.d.) using an Agilent 1100 LC system. Aliquots from tryptic digests were loaded onto the column preequilibrated with deionized water (containing $0.05 \%$ TFA) and then eluted using a gradient from 0 to $70 \%$ acetonitrile (containing $0.045 \%$ TFA) in $100 \mathrm{~min}$ at a flow rate of 0.2 $\mathrm{mL} / \mathrm{min}$. Upon elution the peptides were introduced into a Finnigan MAT LCQ ion trap mass spectrometer and mass spectra recorded in the positive ion mode. The instrument was also setup to collect $\mathrm{ms} / \mathrm{ms}$ spectra of all peptide peaks so that sequence information could be obtained in addition to peptide mass data. The charge-state ion distributions observed in electrospray ionization mass spectra were analyzed using Excalibur software (version 1.2).

\section{Results}

\section{The physical appearance of lysozyme samples changes after freeze-drying and storage}

Lysozyme is a protein that is readily obtained in large amounts, relatively small $(14,306 \mathrm{Da})$ and thus highly amenable to analysis by mass spectrometry, and possesses an enzymatic activity that can be quickly, easily and cheaply determined. Further, this small enzyme has been extensively characterized and would therefore appear to be an ideal model protein with which to investigate a wide range of formulation and storage conditions as described in this work.

The physical appearance of the protein samples after freeze-drying was a white cake tightly filling approximately $10 \mathrm{~mm}$ at the bottom of the vial. The dextran samples appeared more finely textured than the sucrose and trehalose formulated samples (Table 1). Following storage at all times and temperatures investigated in this study, the dextran samples, irrespective of $\mathrm{pH}$, exhibited little difference in appearance apart from a slight shrinkage in the volume (Table 1). With longer and higher temperature storage conditions however, the dextran samples took longer to reconstitute after addition of $1 \mathrm{~mL}$ of water (data not shown). The time taken for complete reconstitution was as long as 15 min which would be unacceptable in the medical setting. The trehalose samples also showed very little change in appearance after storage, the exception being the samples formulated at $\mathrm{pH}$ 6.2 and stored for $24 \mathrm{~h}$ at $90^{\circ} \mathrm{C}$. This combination of carbohydrate and temperature exhibited marked shrinkage as compared with other trehalose samples; however there was no change in the ease with which these samples were reconstituted. In contrast, sucrose formulated samples showed more extreme change in appearance (Table 1). This was particularly noticeable for the sample formulated at $\mathrm{pH} 6.2$ and stored at elevated temperatures. The sample stored at $90^{\circ} \mathrm{C}$ for $24 \mathrm{~h}$ was a hard brown mass at the bottom of the vial and was extremely difficult to redissolve. The sucrose samples formulated at $\mathrm{pH} 7.2$ or $\mathrm{pH} 8.2$ did not exhibit large changes in physical appearance and reconstituted with ease.

\section{Glass transition temperatures $\left(T_{g}\right)$ and water content following freeze-drying}

Typical DSC scans showing heat flow per unit mass as a function of temperature are shown in Figure 1. All the samples with the exception of the sucrose $\mathrm{pH} 6.2$ samples were 
Table 1. The Appearance and Initial Lytic of the Freeze-Dried Lysozyme Samples After Incubation

\begin{tabular}{|c|c|c|c|c|c|c|}
\hline \multirow[b]{2}{*}{ Excipient } & \multirow[b]{2}{*}{$\mathrm{pH}$} & \multicolumn{2}{|c|}{ Incubation } & \multirow[b]{2}{*}{ Appearance } & \multicolumn{2}{|c|}{ Initial Rate $(\Delta \mathrm{OD} / \mathrm{sec})$} \\
\hline & & Time & Temp & & Mean & SD \\
\hline \multirow[t]{3}{*}{ Sucrose } & 6.2 & control & $-80^{\circ}$ & White, lacy & 0.067 & 0.004 \\
\hline & 7.2 & control & $-80^{\circ}$ & White, slightly shrunken & 0.078 & 0.002 \\
\hline & 8.2 & control & $-80^{\circ}$ & White, slightly shrunken & 0.076 & 0.002 \\
\hline \multirow[t]{2}{*}{ Trehalose } & 6.2 & control & $-80^{\circ}$ & White, slightly shrunken & 0.075 & 0.002 \\
\hline & 8.2 & control & $-80^{\circ}$ & White, slightly shrunken & 0.077 & 0.003 \\
\hline \multirow[t]{2}{*}{ Dextran } & 7.2 & control & $-80^{\circ}$ & White, slightly shrunken & 0.084 & 0.001 \\
\hline & 8.2 & control & $-80^{\circ}$ & White, slightly shrunken & 0.093 & 0.001 \\
\hline \multirow[t]{3}{*}{ Sucrose } & 6.2 & $24 \mathrm{~h}$ & $90^{\circ} \mathrm{C}$ & Brown, small, hard & 0.055 & 0.013 \\
\hline & 7.2 & $24 \mathrm{~h}$ & $90^{\circ} \mathrm{C}$ & White, small & 0.105 & 0.004 \\
\hline & 8.2 & $24 \mathrm{~h}$ & $90^{\circ} \mathrm{C}$ & White, shrunken & 0.089 & 0.008 \\
\hline \multirow[t]{3}{*}{ Trehalose } & 6.2 & $24 \mathrm{~h}$ & $90^{\circ} \mathrm{C}$ & White, shrunken & 0.074 & 0.015 \\
\hline & 7.2 & $24 \mathrm{~h}$ & $90^{\circ} \mathrm{C}$ & White, slightly shrunken & 0.115 & 0.003 \\
\hline & 8.2 & $24 \mathrm{~h}$ & $90^{\circ} \mathrm{C}$ & White, slightly shrunken & 0.102 & 0.000 \\
\hline \multirow[t]{3}{*}{ Dextran } & 6.2 & $24 \mathrm{~h}$ & $90^{\circ} \mathrm{C}$ & White, slightly shrunken & 0.068 & 0.001 \\
\hline & 7.2 & $24 \mathrm{~h}$ & $90^{\circ} \mathrm{C}$ & White, slightly shrunken & 0.086 & 0.001 \\
\hline & 8.2 & $24 \mathrm{~h}$ & $90^{\circ} \mathrm{C}$ & White, slightly shrunken & 0.072 & 0.009 \\
\hline \multirow{3}{*}{ Sucrose } & 6.2 & 1 month & $55^{\circ} \mathrm{C}$ & Brown, small, hard & 0.072 & 0.001 \\
\hline & 7.2 & 1 month & $55^{\circ} \mathrm{C}$ & White, slightly shrunken & 0.076 & 0.001 \\
\hline & 8.2 & 1 month & $55^{\circ} \mathrm{C}$ & White, slightly shrunken & 0.076 & 0.001 \\
\hline \multirow[t]{3}{*}{ Trehalose } & 6.2 & 1 month & $55^{\circ} \mathrm{C}$ & White, slightly shrunken & 0.073 & 0.001 \\
\hline & 7.2 & 1 month & $55^{\circ} \mathrm{C}$ & White, slightly shrunken & 0.075 & 0.001 \\
\hline & 8.2 & 1 month & $55^{\circ} \mathrm{C}$ & White, slightly shrunken & 0.078 & 0.001 \\
\hline \multirow[t]{3}{*}{ Dextran } & 6.2 & 1 month & $55^{\circ} \mathrm{C}$ & White, slightly shrunken & 0.075 & 0.002 \\
\hline & 7.2 & 1 month & $55^{\circ} \mathrm{C}$ & White, slightly shrunken & 0.085 & 0.002 \\
\hline & 8.2 & 1 month & $55^{\circ} \mathrm{C}$ & White, slightly shrunken & 0.078 & 0.002 \\
\hline \multirow[t]{3}{*}{ Sucrose } & 6.2 & 16 month & $37^{\circ} \mathrm{C}$ & Off white, small & 0.094 & 0.003 \\
\hline & 7.2 & 16 month & $37^{\circ} \mathrm{C}$ & White, slightly shrunken & 0.097 & 0.001 \\
\hline & 8.2 & 16 month & $37^{\circ} \mathrm{C}$ & White, slightly shrunken & 0.091 & 0.006 \\
\hline \multirow[t]{3}{*}{ Trehalose } & 6.2 & 16 month & $37^{\circ} \mathrm{C}$ & White, slightly shrunken & 0.074 & 0.003 \\
\hline & 7.2 & 16 month & $37^{\circ} \mathrm{C}$ & White, slightly shrunken & 0.075 & 0.004 \\
\hline & 8.2 & 16 month & $37^{\circ} \mathrm{C}$ & White, slightly shrunken & 0.072 & 0.002 \\
\hline \multirow{3}{*}{ Dextran } & 6.2 & 16 month & $37^{\circ} \mathrm{C}$ & White, slightly shrunken & 0.071 & 0.007 \\
\hline & 7.2 & 16 month & $37^{\circ} \mathrm{C}$ & White, slightly shrunken & 0.085 & 0.000 \\
\hline & 8.2 & 16 month & $37^{\circ} \mathrm{C}$ & White, slightly shrunken & 0.082 & 0.001 \\
\hline
\end{tabular}

Lysozyme samples were freeze-dried in $\mathrm{pH} 6.2,7.2$ or 8.2 buffer containing $3 \%$ sucrose, trehalose or dextran prior to incubation (sd, standard deviation).

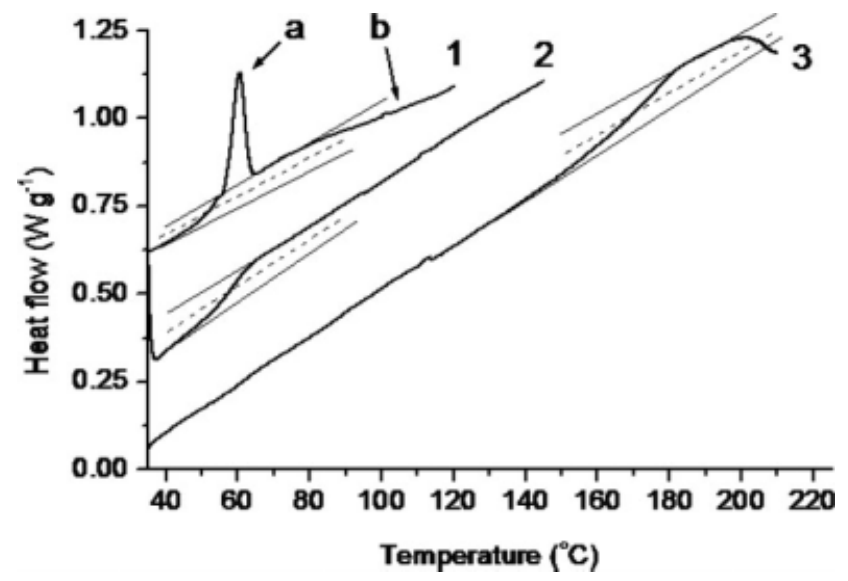

Figure 1. Differential scanning calorimeter (DSC) scans of amorphous lysozyme-carbohydrate $\mathrm{pH} 6.2$ phosphate buffer mixtures to determine their glass transition temperatures $\left(T_{\mathrm{g}} \mathrm{s}\right)$.

(1) Sucrose formulation first scan showing (A) enthalpy relaxation peak, and (B) the onset of an endothermic (buffer) crystallisation peak. (2) Trehalose formulation, rescan. (3) Dextran formulation, rescan. For further details see text.

stable with respect to buffer crystallization when heated above their glass transition temperature. For all such samples a second scan was performed thus removing the effects of physical aging on the scans which can affect the results (20). In the unique case of the sucrose $\mathrm{pH} 6.2$ samples a $T_{\mathrm{g}}$ deter-
Table 2. Glass transition temperature and water content of freeze-dried lysozyme-carbohydrate-phosphate buffer formulations

\begin{tabular}{lccc}
\hline Carbohydrate & $\mathrm{pH}^{*}$ & $T_{\mathrm{g}}\left({ }^{\circ} \mathrm{C}\right)$ & Water Content $(\% \mathrm{w} / \mathrm{w})$ \\
\hline Sucrose & 6.2 & 37.7 & 1.0 \\
& 7.2 & 75.4 & 2.6 \\
Trehalose & 8.2 & 87.3 & 2.5 \\
& 6.2 & 61.0 & 1.0 \\
Dextran & 7.2 & 69.7 & 1.7 \\
& 8.2 & 74.7 & 1.2 \\
& 6.2 & 172.0 & 2.8 \\
& 7.2 & 182.1 & 2.4 \\
& 8.2 & 187.0 & 3.0
\end{tabular}

Prior to freeze-drying each sample contained $5 \mathrm{mg} / \mathrm{mL}$ lysozyme, $3 \%$ w/w carbohydrate and $0.1 \mathrm{M}$ sodium phosphate buffer. $\mathrm{pH}$ refers to value prior to freeze-drying.

* Refers to $\mathrm{pH}$ upon formulation and not in the glassy state.

mined from the first scan as in Figure 1 is reported. All the formulations were glassy at ambient temperatures with glass transition temperatures varying in the range $37.7^{\circ} \mathrm{C}$ for the $\mathrm{pH} 6.2$ sucrose formulation to $187.0^{\circ} \mathrm{C}$ for the $\mathrm{pH} 8.2$ dextran formulation as shown in Table 2. The water contents were low and varied in the range $1.0-3.0 \% \mathrm{w} / \mathrm{w}$ (Table 2). The range of glass transition temperatures means that during incubation in the stability studies the physical state of the samples varied from being wholly in the glass state (dextran samples), largely in the glass state (trehalose samples at $90^{\circ} \mathrm{C}$ are in a viscous liquid state above their glass transition temperature but all other samples are in the glass state) to 
A

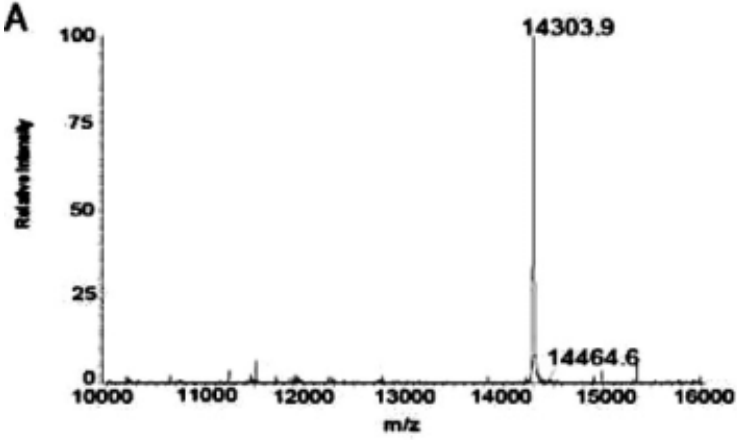

C

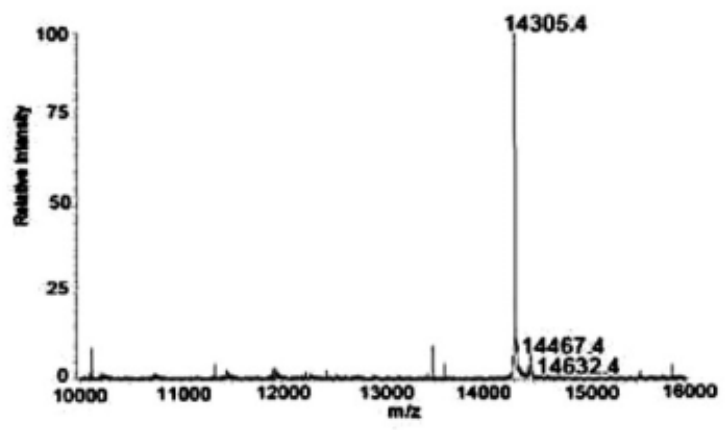

B

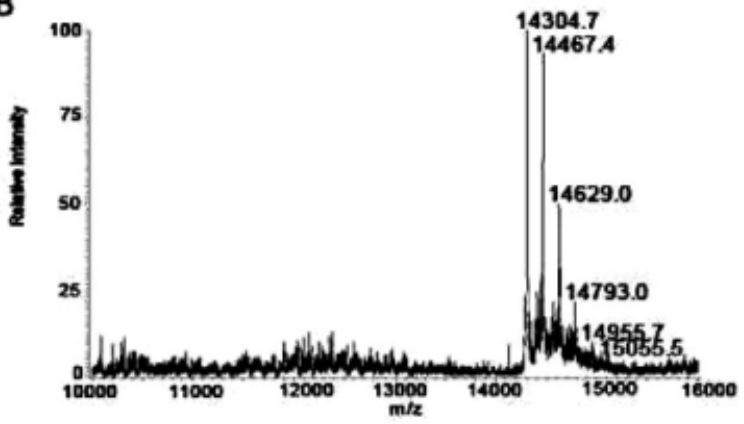

D

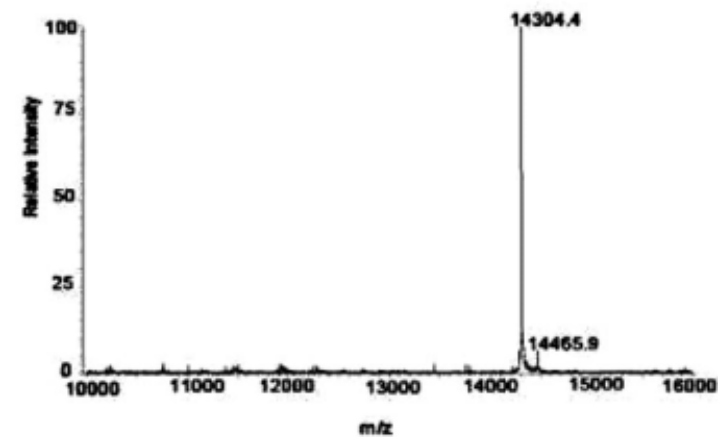

Figure 2. Electrospray ionization mass spectrometry analysis of lysozyme samples formulated in sucrose after freeze-drying and storage for 1 month at $55^{\circ} \mathrm{C}$.

(A) Lysozyme formulated at $\mathrm{pH} 6.2$ at time $=0$ (control sample), (B) lysozyme formulated at $\mathrm{pH} 6.2$ after 1 month at $55^{\circ} \mathrm{C}$, $(\mathrm{C})$ lysozyme formulated at $\mathrm{pH} 7.2$ after 1 month at $55^{\circ} \mathrm{C}$, (D) lysozyme formulated at $\mathrm{pH} 8.2$ after 1 month at $55^{\circ} \mathrm{C}$.

being in both viscous liquid and glass states (pH 6.2 sucrose samples at $37^{\circ} \mathrm{C}$ are in the glass transition region and at higher temperatures are in the viscous liquid states whereas the $\mathrm{pH} 7.2$ and 8.2 samples are only in the viscous liquid states at $90^{\circ} \mathrm{C}$ ). It should be noted that the $T_{\mathrm{g}} \mathrm{s}$ are the initial $T_{\mathrm{g}} \mathrm{s}$ before significant reaction/protein modification has occurred. The glycation reaction produces water as the reaction proceeds and the water content therefore increases which would be expected to depress the $T_{\mathrm{g}}{ }^{23}$

\section{The effect of glass formulation variables and storage conditions upon enzymatic activity}

The lytic activity of lysozyme for the bacterial substrate Micrococcus lysodieticus was used to determine if the enzymatic activity of lysozyme samples was preserved or degraded more efficiently/rapidly under any of the formulation and storage conditions investigated. For this analysis all activities were determined in triplicate and the average is shown in Table 1. As it can be observed from the resulting initial rates calculated and presented in Table 1, there was very little variation in the initial rate at which lysozyme cleared a solution of the bacterial substrate with changing formulation and storage conditions. The largest difference was observed when lysozyme was freeze-dried in sucrose formulated at $\mathrm{pH} 6.2$ and stored at $90^{\circ} \mathrm{C}$ for $24 \mathrm{~h}$ where the initial rate was much lower than that for the other two pH's (Table 1). This trend of the lowest initial rate being observed in samples formulated at $\mathrm{pH} 6.2$ when compared with those formulated at $\mathrm{pH} 7.2$ or $\mathrm{pH} 8.2$ was consistently observed across the majority of storage conditions (Table 1). As such, the data suggest that preformulation of lysozyme at $\mathrm{pH} 6.2$ is likely to result in the greater relative loss of enzymatic ac- tivity regardless of the carbohydrate in the formulation. Further, the data show that lysozyme is a very robust enzyme that retains its activity under a wide range of conditions, even in samples that physically appear modified and therefore may not be the best choice for studying effects on enzymatic activity under such conditions.

\section{Direct ESI mass spectrometry analysis of lysozyme samples confirms chemical modification under certain conditions}

Direct ESI mass spectrometry analysis was undertaken on lysozyme samples upon freeze-drying and storage to determine the extent of any chemical modifications resulting in mass change. As shown in Figure 2A, LC-ESI-MS analysis of a lysozyme sample freeze-dried in sucrose at $\mathrm{pH} 6.2$ prior to storage (time $=0$ ) gave a single peak with a molecular mass of 14,303.9 Da in agreement with the theoretically calculated mass for intact lysozyme. Subsequent analysis of lysozyme freeze-dried in sucrose formulated at $\mathrm{pH}$ 6.2, 7.2, and 8.2 and stored at $55^{\circ} \mathrm{C}$ for 1 month showed obvious chemical modification to some of the protein material (Figures 2B-D). The deconvoluted spectrum of lysozyme samples formulated at $\mathrm{pH} 6.2$ and incubated at $55^{\circ} \mathrm{C}$ contained four well-defined extra peaks observed at 14,467, 14,629, 14,793, and 14,955 Da, respectively (Figure 2B, Table 3) corresponding to increases in mass of multiples of $162 \mathrm{Da}$. This mass change can be assigned to protein modification resulting from the condensation of one unit of glucose or fructose with the amino group of a lysine residue on the surface of the protein. This nonenzymatic process termed protein glycation ${ }^{24,25}$ is possible because of the hydrolysis of sucrose to yield fructose and glucose. ${ }^{26}$ In addition to these well defined peaks, there were other less well-defined peaks/ 
areas within the spectrum indicative of additional chemical modifications or rearrangements that had occurred, but it was not possible to assign these from this data. It is likely that some of these products arise from rearrangement of the glycation adducts to yield advanced glycation end products (AGEs).

Mass spectrometry analysis of lysozyme samples freezedried in sucrose at $\mathrm{pH} 7.2$ and subsequently stored at $55^{\circ} \mathrm{C}$ for 1 month showed less chemical modification than that

Table 3. LC-MS Determined Masses of Lysozyme Samples After Incubation at $55^{\circ} \mathrm{C}$ for 1 Month

\begin{tabular}{|c|c|c|c|c|}
\hline $\mathrm{pH}$ & Excipient & Mass & $\begin{array}{c}\text { Mass } \\
\text { Difference }\end{array}$ & $\begin{array}{c}\text { Identity/ } \\
\text { Assignment }\end{array}$ \\
\hline \multirow[t]{6}{*}{6.2} & Sucrose & 14304.7 & & Lysozyme \\
\hline & & 14467.4 & 162.7 & $1 \times$ glycation \\
\hline & & 14629.0 & 324.3 & $2 \times$ glycation \\
\hline & & 14793.0 & 488.3 & $3 \times$ glycation \\
\hline & & 14955.7 & 651 & $4 \times$ glycation \\
\hline & & 15098.2 & 793.5 & $5 \times$ glycation \\
\hline \multirow[t]{3}{*}{7.2} & Sucrose & 14305.4 & & Lysozyme \\
\hline & & 14467.4 & 162 & $1 \times$ glycation \\
\hline & & 14632.0 & 326.6 & $2 \times$ glycation \\
\hline \multirow[t]{2}{*}{8.2} & Sucrose & 14304.4 & & Lysozyme \\
\hline & & 14465.9 & 161.5 & $1 \times$ glycation \\
\hline \multirow[t]{2}{*}{6.2} & Trehalose & 14304.7 & & $\begin{array}{l}\text { Lysozyme } \\
\times \text { glycation }\end{array}$ \\
\hline & & 14630.2 & 325.5 & $2 \times$ glycation \\
\hline 7.2 & Trehalose & 14304.5 & & Lysozyme \\
\hline 8.2 & Trehalose & 14304.4 & & Lysozyme \\
\hline 6.2 & Dextran & 14303.6 & & Lysozyme \\
\hline 7.2 & Dextran & 14304.0 & & Lysozyme \\
\hline 8.2 & Dextran & 14304.4 & & Lysozyme \\
\hline
\end{tabular}

Lysozyme samples were freeze-dried in $\mathrm{pH} 6.2,7.2$ or 8.2 buffer containing 3\% sucrose, trehalose or dextran.

A

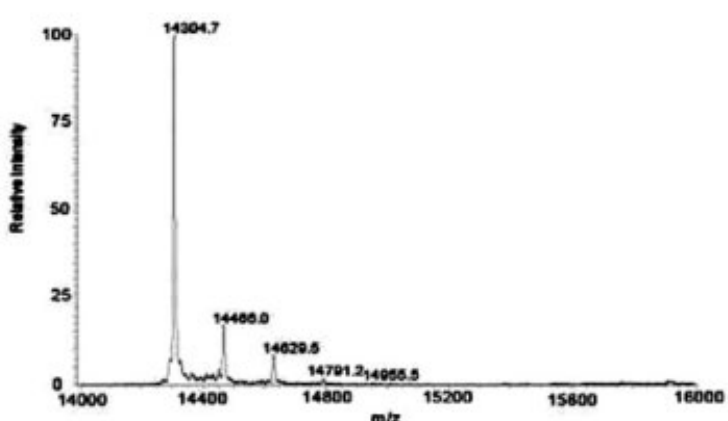

C

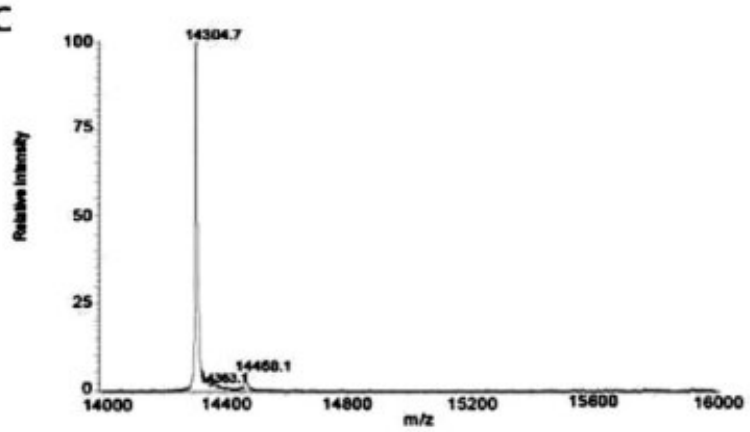

observed at $\mathrm{pH} 6.2$ with only two of these extra peaks present in the deconvoluted spectra; those at 14,467 and 14,632 Da, respectively (Figure 2C). The extent of chemical modification was even less in those samples formulated before freeze-drying in sucrose at $\mathrm{pH} 8.2$ with just one of these major additional peaks being observed, that at 14,466 Da, suggesting that less glycation occurs under these conditions. A clear relationship between the $\mathrm{pH}$ before freeze-drying and protein glycation was therefore apparent. We note that the glycation of proteins can suppress or change its ionization behavior, therefore, although the relative levels of glycated and nonglycated material cannot be calculated from these data, the relative levels of each glycated product can be directly compared and thus allows the comparisons and conclusions drawn above to be made.

When sucrose formulated samples were stored at lower temperatures but for longer periods of time a similar trend was observed (Figure 3). Sucrose samples stored at $37^{\circ} \mathrm{C}$ for 16 months after formulation at $\mathrm{pH} 6.2$ prior to freeze-drying once again showed chemical modification of up to 4 discrete higher masses; 14,466, 14,629.5, 14,791.2, and 14,955.5 Da corresponding to glycation events (Figure 3A). In addition, various other species were once again present and detectable between the unmodified protein $(14,304.7 \mathrm{Da})$ and the peaks at 14,466 and $14,629.5$ Da (Figure 3A), indicative of further undefined modifications occurring. Despite these changes, the lytic activity of such samples was not changed compared with those formulated at $\mathrm{pH} 7.2$ or $\mathrm{pH} 8.2$ (Table 1) where there was little evidence of modification. For samples formulated in sucrose at $\mathrm{pH} 7.2$ prior to freeze-drying and storage for 16 months at $37^{\circ} \mathrm{C}$ only one of the glycation peaks was detected $(14,465.2 \mathrm{Da})$ along with a small amount of other modified material between this and the unmodified peak

B
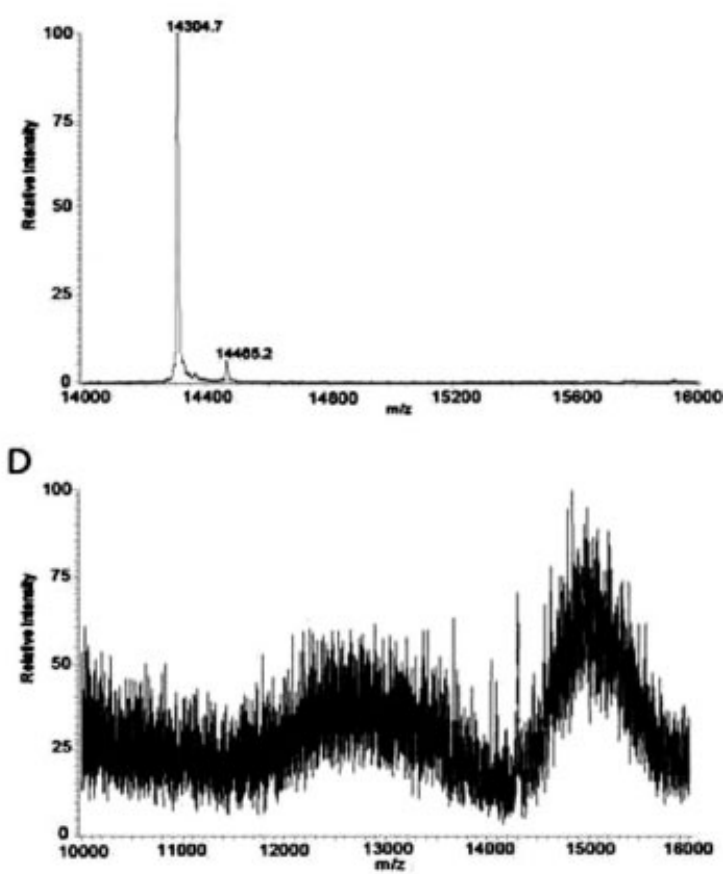

Figure 3. Electrospray ionization mass spectrometry analysis of lysozyme samples formulated in sucrose after freeze-drying and storage at various times and temperatures.

(A) lysozyme formulated at $\mathrm{pH} 6.2$ after 16 months at $37^{\circ} \mathrm{C}$, (B) lysozyme formulated at $\mathrm{pH} 7.2$ after 16 months at $37^{\circ} \mathrm{C}$, (C) lysozyme formulated at $\mathrm{pH} 8.2$ after 16 months at $37^{\circ} \mathrm{C}$, (D) lysozyme formulated at $\mathrm{pH} 6.2$ after $24 \mathrm{~h}$ at $90^{\circ} \mathrm{C}$. 
(Figure 3B). A similar profile to that of the $\mathrm{pH} 7.2$ samples was observed in those samples formulated in sucrose at $\mathrm{pH}$ 8.2 prior to freeze-drying and storage at $37^{\circ} \mathrm{C}$ for 16 months (Figure 3C).

In contrast to the previous results, when samples formulated in sucrose at $\mathrm{pH} 6.2$ prior to freeze-drying were stored at $90^{\circ} \mathrm{C}$ for $24 \mathrm{~h}$ the spectra was highly variable and the main peak was observed as a broad peak at or around $15,000 \mathrm{Da}$ indicative of the protein being modified to different degrees and with varying modifications (Figure 3D). It was not possible to assign any of the potential modifications from this data. Interestingly, in this sample there appears to be a further broad peak centered just below 13,000 Da suggesting degradation of some of the material in addition to those chemical modifications leading to an increase in the observed mass (Figure 3D). This agrees with the enzymatic data whereby the lytic activity of this sample was reduced compared with the samples at $90^{\circ} \mathrm{C}$ for $24 \mathrm{~h}$ formulated at $\mathrm{pH} 7.2$ or 8.2 (Table 1 ). Together, these results confirm that the temperatures and times investigated are sufficient for accelerated stability studies in order to "force" modifications. We also note that these temperatures are used routinely within industry for such investigations.

When lysozyme was freeze-dried using trehalose as the carbohydrate and then subjected to accelerated stability studies, there was little evidence by intact mass spectrometry that chemical modification or loss of protein integrity had occurred under any of the conditions investigated (Table 3). Only those samples formulated in trehalose at $\mathrm{pH} 6.2$ prior to freeze-drying and then stored subsequently at $90^{\circ} \mathrm{C}$ for $24 \mathrm{~h}$ showed readily observable, but still minor, degrees of chemical modification. This agrees with the enzymatic activity data whereby comparison of the trehalose samples stored at $90^{\circ} \mathrm{C}$ showed that those formulated at $\mathrm{pH} 6.2$ had significantly lower enzymatic activity than those at 7.2 or 8.2 (Table 1). The deconvoluted spectra of samples freeze-dried and stored in this way showed one defined additional peak $(14,628.5 \mathrm{Da})$ along with a small amount of material indicative of other chemical modification. Formulation at higher $\mathrm{pH}$ or more extreme storage conditions resulted in little detectable modification. For all dextran samples, there was no evidence of chemical modification under any of the conditions investigated.

\section{Tryptic mapping confirms glycation and deamidation are the major chemical modifications to lysozyme under the freeze-dried conditions investigated}

Mass spectrometry analysis of lysozyme samples following freeze-drying and storage showed conclusively that time, temperature and formulation variables determined the extent, and type, of chemical modification observed. However, although such analysis can confirm the presence of chemical modification it does not allow identification of which amino acids are modified within the protein, or the unambiguous assignment of small mass change modifications such as deamidation. Lysozyme samples that had been freeze-dried and stored at $55^{\circ} \mathrm{C}$ for 1 month were therefore subjected to tryptic peptide mapping in order to determine which amino acid residues were modified and to more fully characterize the observed modifications. The resulting tryptic peptides were then separated by reverse phase HPLC and ESI mass spectrometry (Figure 4 and Table 4 ).

The expected tryptic peptides from lysozyme were initially identified from their masses and later confirmed by tandem mass spectrometry analysis (Table 4 and Figure 4). Confirmation of glycation, and therefore the glycated lysine residue, was relatively straightforward as trypsin does not cleave after glycated lysine residues and therefore glycated peptides contain an uncleaved lysine residue. ${ }^{27}$ In addition to an uncleaved lysine residue, glycated peptides are detected in the mass spectrometer as $162 \mathrm{Da}$ greater in mass than would be expected in the absence of glycation due to the presence of the sugar residue. Modifications and their site(s) were also confirmed by tandem mass spectrometry analysis.

Glycation was observed at all six lysine $(\mathrm{K}=$ lysine $)$ residues within lysozyme during this study when samples were formulated in sucrose (Table 4). Most glycation was observed at lysine residues 96 and 33 as determined from the HPLC UV traces (Figure 4). The extent of glycation varied with the formulation, with samples formulated at $\mathrm{pH} 6.2$ in sucrose prior to freeze-drying giving rise to the greatest extent of modification. In samples treated in this manner 3 of the glycation sites, $\mathrm{K}^{33}$ in peptide $\mathrm{T} 6+\mathrm{T} 7, \mathrm{~K}^{97}$ in $\mathrm{T} 12+\mathrm{T} 13$, and $\mathrm{K}^{116}$ in $\mathrm{T} 15+\mathrm{T} 16$ were visible as extra peaks in the UV traces (Figure 4). Whilst the other three glycation sites detected did not give rise to new, clearly visible peaks in the UV spectra, these were clearly present when the mass spectra data was analyzed in detail, suggesting that these sites are less susceptible to protein glycation. With increasing $\mathrm{pH}$, fewer lysines were glycated and the peaks for those that were detected appeared smaller than the corresponding peaks observed in the $\mathrm{pH} 6.2$ samples (Figure 4). As expected, there was much less evidence of protein glycation in trehalose formulated freeze-dried samples agreeing with the data for the intact protein (Table 4). Further, as expected there was no evidence of glycation in dextran samples in agreement with data from the intact protein mass spectrometry analysis (Table 4).

The tryptic mapping and $\mathrm{ms} / \mathrm{ms}$ analysis also revealed that deamidation had occurred to lysozyme samples. Deamidation of $\mathrm{N}^{103}$ was observed in all samples (peaks $7 \mathrm{~h}$ and $7 \mathrm{j}$, Figure 4) and has previously been observed in control samples in other studies suggesting that this is not related to the freezedrying or formulation variables investigated in this study. ${ }^{13}$ However, there was an additional deamidation peak corresponding to $\mathrm{N}^{103}$ which was only detected in samples formulated in sucrose at $\mathrm{pH} 6.2$ prior to freeze-drying (Table 4). There was no evidence of other commonly observed modifications such as methionine oxidation, however, there were peptide peaks and masses within these spectra which we were not able to assign on the basis of mass alone and the appearance of several of these did exhibit formulation dependent tendencies suggesting that additional, but as yet uncharacterized modifications, do arise under the variables investigated.

\section{Discussion}

The integrity of protein based products such as biotherapeutic pharmaceuticals (e.g. monoclonal antibodies) must be preserved prior to administration in order to prevent immunogenicity and maintain bioactivity. Similarly, the structure of proteins in food ingredients must be maintained in order to retain their functionality prior to use. Plant anhydrobiotes can preserve biological activity of proteins by accumulating sugars in their tissues during drying and transforming the cytoplasm into a glassy state. ${ }^{28} \mathrm{~A}$ similar approach has been applied to the stabilization of high-value therapeutic proteins 

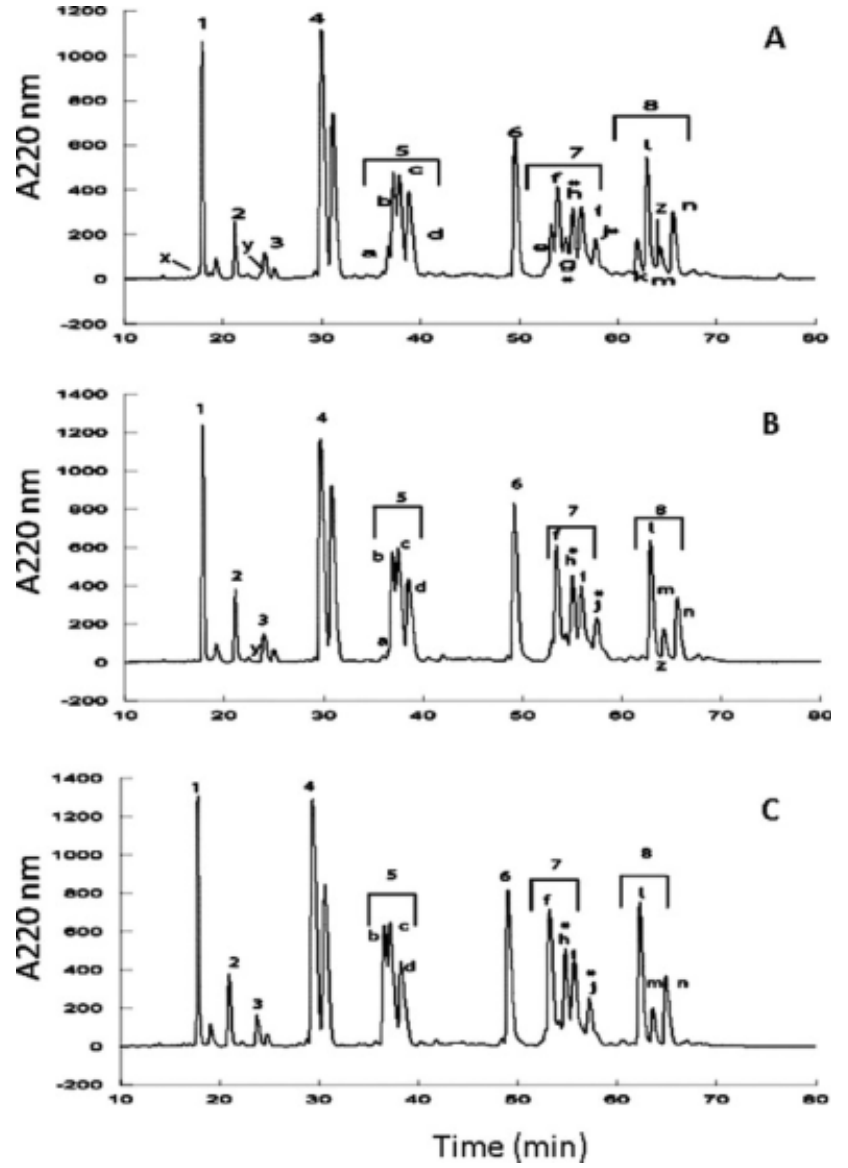

Figure 4. Reversed-phase HPLC separation of the tryptic peptides of lysozyme formulated (A) sucrose at $\mathrm{pH} 6.2$ before freeze-drying and storage at $55^{\circ} \mathrm{C}$ for 1 month, (B) sucrose at $\mathrm{pH} 8.2$ before freeze-drying and storage at $55^{\circ} \mathrm{C}$ for 1 month, and (C) trehalose at pH 6.2 before freeze-drying and storage at $55^{\circ} \mathrm{C}$ for 1 month.

The peptides are labeled to correspond to the peaks and assignments listed in Table 4. Deamidation modifications are depicted with a $\operatorname{star}(*)$.

whereby they are preserved in the glassy state following freeze-drying in a carbohydrate based formulation. ${ }^{18}$ There has been considerable work undertaken on how formulation and storage temperature of protein glasses affects the rates at which proteins aggregate or lose their biological activity; however, our understanding of the molecular mechanisms of protein stabilization and chemical modification in glasses is incomplete. We, therefore, investigated the relationship between chemical modification and rate thereof with variation of $\mathrm{pH}$, temperature, and the glass transition temperature using the most commonly used carbohydrate additive for the formation of mixed protein-carbohydrate glasses (sucrose) as well as trehalose and dextran to further our understanding of the mechanisms and processes involved.

The glass transition temperature of these mixed formulations depends upon all the compositional variables i.e., the amount of carbohydrate, monosodium phosphate, disodium hydrogen phosphate, lysozyme, and water. The relative amount of the phosphate salts depends upon the buffer's $\mathrm{pH}$. Whilst the present dataset is insufficiently large to distinguish effects of all the variables there was a clear difference between the $T_{\mathrm{g}}$ of the disaccharide-based formulations (sucrose, trehalose) and the higher molecular weight polysaccharide-based formulations (dextran) which reflects the higher glass transition temperature of the polysaccharide excipient in its pure dry amorphous form which has been reported as $189^{\circ} \mathrm{C}$ for dextran ${ }^{29}$ when compared with 67 and $111^{\circ} \mathrm{C}$ for sucrose $\mathrm{s}^{30}$ and trehalose $\mathrm{s}^{31}$ respectively. The sodium phosphate buffer, water content and the protein itself have secondary effects on the $T_{\mathrm{g}}$ of the freeze-dried formulations. The $T_{\mathrm{g}}$ 's of all the formulations increase with $\mathrm{pH}$ in agreement with data reported by Ohtake et al. ${ }^{32}$ who reported that sucrose- and trehalose-phosphate buffer formulations dried from higher $\mathrm{pH}$ (richer in disodium hydrogen phosphate) have higher $T_{\mathrm{g}}{ }^{\prime} \mathrm{s}$. We note that the relatively low $T_{\mathrm{g}}$ of the sucrose $\mathrm{pH} 6.2$ formulation has a composition which is in the vicinity of a phase separation ${ }^{32}$ and that in samples formulated at $\mathrm{pH} 7.2$ and 8.2 the $T_{\mathrm{g}}$ 's of sucrose were higher than those of trehalose, reversing the relationship between these observed at $\mathrm{pH}$ 6.2. The $\mathrm{pH} 7.2$ and 8.2 sucrose formulations have $T_{\mathrm{g}}$ 's above that of pure dry sucrose indicating a positive contribution of the buffer and protein to the overall glass transition temperature of the mixture despite the presence of water which generally acts as a plasticiser, depressing the glass transition temperature of the mixture. ${ }^{33}$

The relationship between $T_{\mathrm{g}}$, carbohydrate, $\mathrm{pH}$ of formulation, temperature of storage, physical appearance, and the degree of chemical modification observed is summarized in Figure 5. The observed physical structure of the freeze-dried formulations after incubation at elevated temperatures (Table 1) were directly related to the changing material properties of these amorphous materials as they were heated through their glass transitions (Table 2 and Figure 5A). At temperatures in excess of $T_{\mathrm{g}}$, the materials transform from a solid-like glass to a highly viscous liquid. The viscosity of the liquid decreases rapidly with increasing temperature such that within $10^{\circ} \mathrm{C}$ of $T_{\mathrm{g}}$ the material is sufficiently soft for surface tension to cause the initially porous low density structure to rapidly collapse, losing much of its porosity and forming a compact high density liquid structure. ${ }^{34}$ This collapse is a kinetic process, its rate predicted to be proportional to the viscosity of the liquid phase. ${ }^{35}$ With prolonged storage, as in the 16 month incubation at $37^{\circ} \mathrm{C}$, the collapse effect is observed at temperatures in the region of the glass transition itself as is observed for the sucrose pH 6.2 formulation (Table 1).

There have been a number of studies that have investigated the effect of different buffer formulations on protein integrity, however, in most cases overall changes in secondary structure have been studied using techniques such as FTIR but detailed studies of any chemical modifications are rare. Also, the linking of formulation to activity is not common. ${ }^{5,11,36}$ There was an obvious change in lytic activity only in those lysozyme samples formulated in pH 6.2 buffer and heated for $24 \mathrm{~h}$ at $90^{\circ} \mathrm{C}$ (Table 2). However, here we have shown that while changes in activity are not always measurable (Table 2), there may be chemical modification to the protein (Table 3 ) occurring that could potentially lead to changes in the antigenicity of the protein.

We note that both chemical and physical variables affect the rate and extent of protein modifications in accelerated thermal stability tests of freeze-dried formulations. While the effects of some of the chemical and physical variables can be distinguished, others could not be due to the variables being correlated. The chemical variable is the nature of the excipient (sucrose, trehalose, dextran) and the physical variables are temperature, $\mathrm{pH}$ (prior to freeze-drying) and the physical state of the formulation (nonglassy/glassy, viscosity, etc.). While the effect of the change in $\mathrm{pH}$ on the rate of 


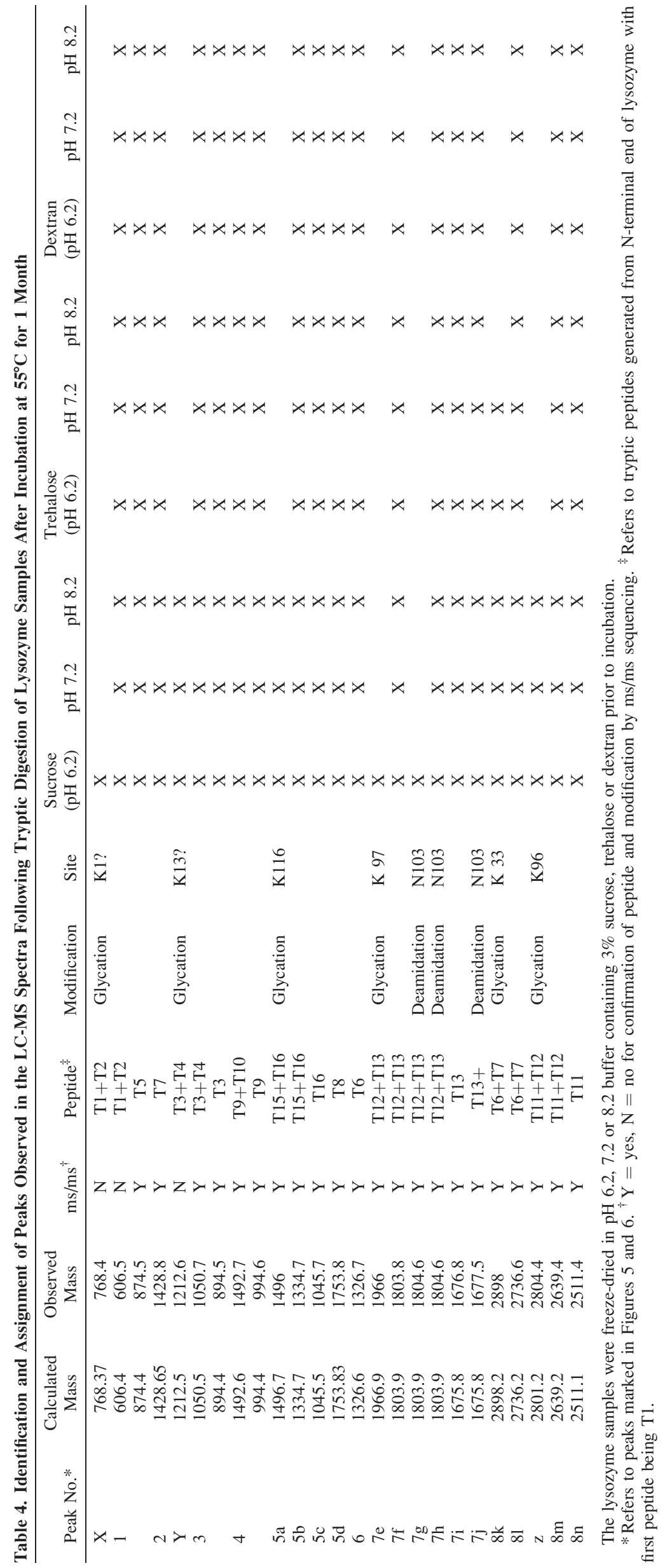



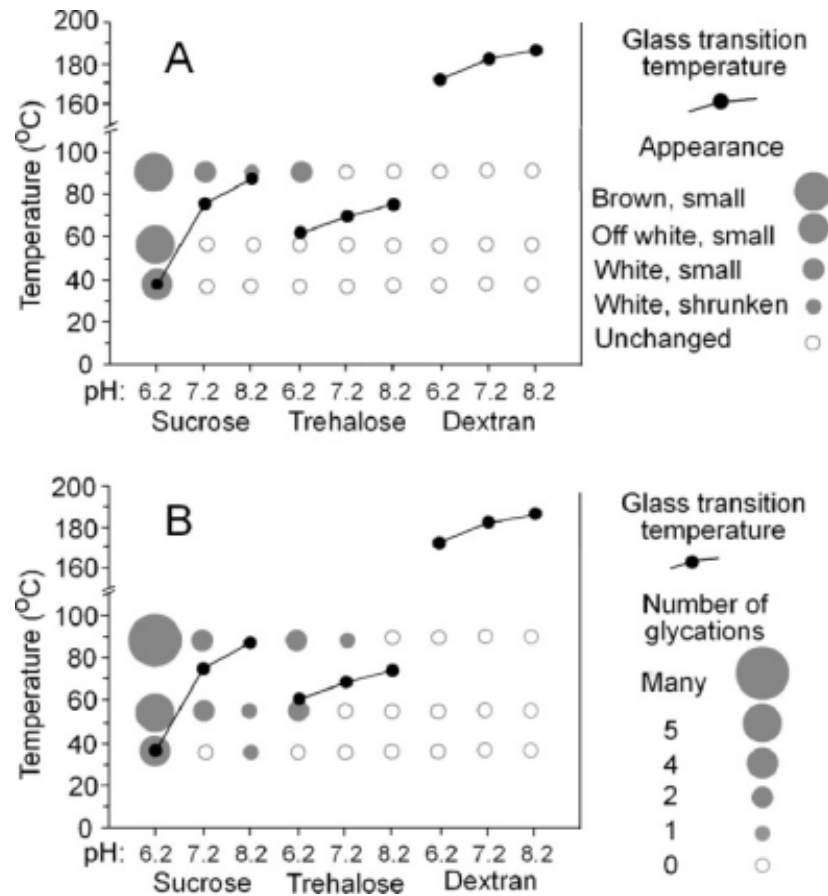

Figure 5. The relationship between the carbohydrate excipient (sucrose, trehalose or dextran), storage condition $\left(37^{\circ} \mathrm{C}\right.$ for 16 months, $55^{\circ} \mathrm{C}$ for 1 month, $90^{\circ} \mathrm{C}$ for 24 h), glass transition $\left(T_{g}\right)$ and (A) physical appearance of samples, and (B) degree of glycation observed.

The physical appearance and degree of glycation are most obviously affected in samples above the $T_{g}$, however modification and changes to the physical appearance were observed in both sucrose and trehalose samples below the $T_{g}$ indicative of changes occurring in the glass. For further details see text.

protein modification may be causal, another factor to be considered is the physical state of the formulations. The $3 \%$ sucrose $\mathrm{pH} 6.2$ formulation has a glass transition temperature of $37.7^{\circ} \mathrm{C}$ and so this system is in the vicinity of the glass transition at $37^{\circ} \mathrm{C}$ and in a viscous liquid state at 55 and $90^{\circ} \mathrm{C}$ and this is the system which reacts most extensively. Several of the glassy systems (sucrose at pH 7.2 and 8.2 and trehalose at $\mathrm{pH} 6.2$ and 7.2) show more limited reaction (Tables 3, 4 and Figure 5B). For the sucrose formulations the $\mathrm{pH}$ variable is correlated with the changing physical state, for example at $55^{\circ} \mathrm{C}$ as the $\mathrm{pH}$ increases from 6.2 to 8.2 the systems state changes from a viscous liquid state $(\mathrm{pH}$ $\left.6.2, T_{g} 37.7^{\circ} \mathrm{C}\right)$ to a glass $\left(\mathrm{pH} 7.2, T_{\mathrm{g}} 75.4^{\circ} \mathrm{C}\right.$ and $\mathrm{pH} 8.2, T_{\mathrm{g}}$ $87.3^{\circ} \mathrm{C}$ ). However, although the chief chemical modification observed (glycation) was more abundant in the sucrose sample formulated at $\mathrm{pH} 6.2$ at temperatures when it would no longer be expected to be glassy, modification was clearly occurring in sucrose and trehalose samples that were in the glassy state (Figure 5B).

Although deamidation was detected across most of the formulations and variables investigated (Table 4), the most prominent modification was protein glycation. Glycation results from reaction with glucose and/or fructose which in the formulations investigated here is the product of degradation of the carbohydrate excipients. The degradation process generating the reducing sugars depends upon the nature of the excipient, temperature and $\mathrm{pH}$ such that the levels of reducing sugar generated followed the trend sucrose $>$ trehalose $>$ dextran. We note that $\mathrm{pH}$ directly affects the rate of glycation as it changes both the rate of sucrose hydrolysis and the nucleophilicity of lysine residues. On this basis of the extent of glycation in our formulations follows from the concentration of reducing sugars present. In addition to the identity of the carbohydrate excipient the protein modifications vary with the $\mathrm{pH}$ of the formulations. For both the sucrose and the trehalose formulations the extent of protein modification, as shown from the results of the LC-MS of the intact lysozyme (e.g. Table 3 ) and the peptide mapping (e.g. Table 4), increase as the $\mathrm{pH}$ decreases from 8.2 through 7.2 to 6.2 . At $55^{\circ} \mathrm{C}$, the trend occurs for both the trehalose formulations which are all in a solid glassy state and for the sucrose formulations which are glassy at $\mathrm{pH} 8.2$ and 7.2 and are in a viscous liquid state at $\mathrm{pH}$ 6.2.

The peptide mapping results shown in Table 4 reveal that the glycation of lysine residues varies with site although all six residues are glycated under at least one of the conditions investigated. Although it is difficult to precisely determine the different lysine reactivities from this data, lysines 1 and 97 appear to be the least reactive under the conditions investigated whilst lysine 33 appears to be the most such that the reactivity varies in the order $\mathrm{K}^{33}>\mathrm{K}^{13}, \mathrm{~K}^{116}, \mathrm{~K}^{96}>\mathrm{K}^{1}, \mathrm{~K}^{97}$. Although reactions of $\mathrm{K}^{1}$ and $\mathrm{K}^{97}$ occurred solely in the liquid pH 6.2 sucrose formulations, the other residues showed reaction in the glass state. Lysine residue $\mathrm{K}^{33}$ is presumably the most reactive with glycation occurring at this site preferentially in the trehalose formulations. This order differs from that previously reported for lysine glycation of lysozyme in solution whereby $\mathrm{K}^{97}$ was the most reactive. Further, $\mathrm{K}^{97}$ is part of a di-lysine motif and it is generally accepted that these are more susceptible to glycation due to local acid-base catalysis making one residue more nucelophilic. ${ }^{36}$ The fact that $\mathrm{K}^{97}$ was least reactive in the freeze-dried samples investigated here suggests that the local structural environment, accessibility, and charge of the lysine residues is different to that found in solution and crystal forms. Further studies to elucidate such differences between the solution and glassy state are therefore required and we note that previous studies in solution using peptide models have shown that the local environment does influence the rate of glycation and local secondary structure elements on glycation. ${ }^{37}$

\section{Conclusions}

Considering all the data together, we have described the characterization of two aspects of stability, chemical stability characterized using mass spectrometry, and the maintenance of biological activity characterized using an enzyme activity assay. We have studied these, both above and below the glass transition of initially amorphous formulations. Perhaps most importantly, we have identified that the rate of protein modification and preferential sites for reaction differ between the solution and glassy state, at least for nonenzymatic glycation. This has implications for predicting likely protein modifications, and sites thereof, to proteins in the glassy state from data previously gathered in the solution state. Further, although dextran formulated samples appeared to be the most stable by our criteria, practically these samples were difficult to resolubilized/reconstitute, which often took several hours rendering them impractical commercially. There were also clear trends between protein modification and buffer $\mathrm{pH}$ prior to freeze-drying and the primary modification detected, glycation, however the differences in the apparent reactivities of the lysine residues for glycation after freeze-drying compared with those previously determined in solution has clear implications for the prediction of potential 
modifications in the glassy state. Further, we predict that whilst the relationship between formulation variables, $T_{\mathrm{g}}$ and the physical attributes of proteins in the glassy state is likely to hold for the majority of proteins, that the relationship between formulation variables and chemical modification will change as a result of the different environments that individual amino acids experience on freeze-drying.

\section{Acknowledgments}

This work was supported by grants BB/C504600/1, BB/ C504478/1 and the Central Strategic Grant to the Institute of Food Research from the Biotechnology and Biological Sciences Research Council (BBSRC), U.K.

\section{Literature Cited}

1. Alikhani ZB, Alikhani M, Boyd CM, Nagao K, Trackman PC, Graves DT. Advanced glycation endproducts enhance expression of pro-apoptotic genes and stimulate fibroblast apoptosis through cytoplasmic and mitochondrial pathways. J Biol Chem. 2005;280:12087-12095.

2. Goolcharran C, Jones AJ, Borchardt RT, Cleland JL, Keck R. Comparison of the rates of deamidation, diketopiperazine formation and oxidation in recombinant human vascular endothelial growth factor and model peptides. AAPS PharmSci. 2000;2: Art. No. 5.

3. Daugherty AL, Mrsny RJ. Formulation and delivery issues for monoclonal antibody therapeutics. Adv Drug Deliv Rev. 2006; 58:686-706.

4. Wang W, Singh S, Zeng DL, King K, Nema S. Antibody structure instability and formulation. J Pharm Sci. 2006;96:1-26.

5. Liao YH, Brown MB, Nazir T, Quader A, Martin GP. Protective mechanism of stabilizing excipients against dehydration in the freeze-drying of proteins. Pharm Res. 2002;19:1854-1861.

6. Liao YH, Brown MB, Martin GP. Investigation of the stabilisation of freeze-dried lysozyme and the physical properties of the formulations. Eur J Pharm Biopharm. 2004;58:15-24.

7. Wang W. Lyophilisation and development of solid pharmaceuticals. Int J Pharm. 2000;203:1-60.

8. Chang BS, Beauvais RM, Dong AC, Carpenter JF. Physical factors affecting the storage stability of freeze-dried interleukin I receptor antagonist: glass transition and protein conformation. Arch Biochem Biophys. 1996;331:249-258.

9. Franks F, Hatley RHM, Mathias SF. Materials science and the production of shelf stable biologicals. BioPharm. 1991;4:38-55.

10. Tanaka K, Takeda T, Miyajima K. Cryoprotective effect of saccharides on denaturation of catalase by freeze-drying. Chem Pharm Bull. 1991:39:1091-1094.

11. Eriksson JHC, Hinrichs WLJ, de Jong GJ, Somsen GW, Frijlink HW. Investigations into the stabilisation of drugs by sugar glasses: III. The influence of various high-pH buffers. Pharm Res. 2003;20:1437-1443.

12. Smales CM, Pepper DS, James DC. Protein modification during antiviral heat bioprocessing. Biotechnol Bioeng. 2000;67:177-188.

13. Brownsey GJ, Noel TR, Parker R Ring SG. The glass transition behaviour of the globular protein bovine serum albumin. Biophys J. 2003;85:3943-3950.

14. Crowe JH, Carpenter JF, Crowe LM. The role of vitrification in anhydrobiosis. Annu Rev Physiol. 1998;60:73-103.

15. Zheng X, Wu SL, Hancock WS. Glycation of interferon-beta- $1 \beta$ and human serum albumin in a lyophilized glucose formulation Part III: application of proteomic analysis to the manufacture of biological drugs. Int J Pharm. 2006;322:136-145.

16. Fischer S, Hoernschemeyer J Mahler HC. Glycation during storage and administration of monoclonal antibody formulations. Eur J Pharm Biopharm. 2008;70:42-50.

17. Chang LQ, Shepherd D, Sun J, Ouellette D, Grant KL, Tang XL, Pikal MJ. Mechanism of protein stabilization by sugars during freeze-drying and storage: native structure preservation, specific interaction, and/or immobilization in a glassy matrix? J Pharm Sci. 2005;94:1427-1444.

18. Allison SD, Chang B, Randolph TW, Carpenter JF. Hydrogen bonding between sugar and protein is responsible for inhibition of dehydration-induced protein unfolding. Arch Biochem Biophys. 1999;365:289-298.

19. Imamura K, Fukushima A, Sakaura K, Sugita T, Sakiyama T, Nakanishi K. Water sorption and glass transition behaviors of freeze-dried sucrose-dextran mixtures. J Pharm Sci. 2002;91: 2175-2181.

20. Noel TR, Ring SG, Whittam MA. Kinetic aspects of the glasstransition behaviour of maltose-water. Carbohydr Res 1991;212: 109-117.

21. Craig ID, Parker R, Rigby NM, Cairns P, Ring SG. Maillard reaction kinetics in model preservation systems in the vicinity of the glass transition: experiment and theory. J Agric Food Chem. 2001;49:4706-4712.

22. Wunderlich B. Thermal Analysis. Boston: Academic Press, Inc; 1990:101.

23. Roos YH, Jouppila K, Zielasko BJ. Non-enzymatic browninginduced water plasticisation-glass transition temperature depression and reaction kinetics determination using DSC. Therm Anal Calorim. 1996;47:1437-1450.

24. Lapolla A, Fedele D, Aronica R, Baldo L. Glycation of lysozyme and the influence of buffer concentration investigated by mass spectrometry. Rapid Commun Mass Spectrom 1996;10: $1512-1518$

25. Vasan S, Zhang X, Zhang XN, Kapurniotu A, Bernhagen J, Teichberg S, Basgen J, Wagle D, Shih D, Terlecky I, Bucala R, Cerami A, Egan J, Ulrich P. An agent cleaving glucose-derived protein crosslinks in vitro and in vivo. Nature 1996;382:275-278

26. Knevelman A, Dewit HJC, Griffin B, Hart H, McIntosh RV. Effect of monosaccharides during severe dry heat-treatment of coagulation-factor-Viii concentrates. Vox Sang. 1994;66:96-103.

27. Zhao H-R, Smith JB, Jiang XY, Abraham EC. Sites of glycation of betaB2 crystallin by glucose and fructose. Biochem Biophys Res Commun. 1996;229:128-133.

28. Bizot H, Le Bail P, Leroux B, Davy J, Roger P, Buleon A. Calorimetric evaluation of the glass transition in hydrated, linear and branched polyanhydroglucose compounds. Carbohydr Polym. 1997;32:33-50.

29. Roos Y. Melting and glass transitions of low molecular weight carbohydrates. Carbohydr Res. 1993;238:39-48.

30. Crowe LM, Reid DS, Crowe JH. Is trehalose special for preserving dry biomaterials? Biophys J. 1996;71:2087-2093.

31. Ohtake S, Schebor C, Palecek SP, de Pablo, JJ. Effect of pH, counter ion, and phosphate concentration on the glass transition temperature of freeze-dried sugar-phosphate mixtures. Pharm Res. 2004;21:1615-1621.

32. Orford PD, Parker R, Ring SG, Smith AC. Effect of water as a diluent on the glass transition behaviour of malto-oligosaccharides, amylose and amylopectin. Int J Biol Macromol. 1989;11: 91-6.

33. Shalaev EY, Franks F. Structural glass transitions and thermophysical process in amorphous carbohydrates and their supersaturated solutions. J Chem Soc Faraday Trans. 1995;91:1511-1517.

34. Downton GE, Flores-Luna JL, King CJ. Mechanism of stickiness in amorphous hygroscopic powders. Ind Eng Chem Fund. 1982;21:447-451.

35. Lee SL, Hafeman AE, Debenedetti PG, Pethica BA, Moore DJ. Solid-state stabilization of chymotrypsin and catalase with carbohydrates. Ind Eng Chem Res. 2006;45:5134-5147.

36. Howard MJ, Smales CM. NMR analysis of synthetic human serum albumin alpha-helix 28 identifies structural distortion upon Amadori modification. $J$ Biol Chem 2005;280:22582-22589.

37. Povey JF, Howard MJ, Williamson RA, Smales CM. The effect of peptide glycation on local secondary structure. J Struct Biol. 2008;161:151-161.

Manuscript received July 9, 2008, and revision received Nov. 29, 2008. 